\title{
A cohort evaluation on arterial stiffness and hypertensive disorders in pregnancy
}

\author{
Wai Yee Lim³ ${ }^{3}$ Seang Mei Saw ${ }^{2,3}$, Kok Hian Tan ${ }^{1,2}$, George SH Yeo ${ }^{1,2}$ and Kenneth YC Kwek ${ }^{1,2^{*}}$
}

\begin{abstract}
Background: Hypertensive disorders in pregnancy are associated with systemic endothelial dysfunction leading to impaired physiological vasodilation. Recent evidence has shown central aortic pressures obtained through pulse wave analysis, at less than 14 weeks of gestation, to be predictive of pre-eclampsia. In light of this, we aimed to evaluate the role of central aortic stiffness in the prediction and discrimination of hypertensive disorders in pregnancy.

Methods: A cohort study of women with viable, singleton pregnancies at less than 14 weeks of amenorrhoea, and without multiple pregnancies, autoimmune or renal disease, diagnosed with aneuploidy or fetal anomaly will be recruited from a single maternity hospital and followed up till delivery and puerperium. A targeted sample size of 1000 eligible pregnant women will be enrolled into the study from antenatal clinics. Main exposure under study is central aortic pulse pressure using radial pulse wave recording, and the outcomes under follow-up are gestational hypertension and pre-eclampsia. Other measures include lifestyle factors such as smoking, physical exercise, psychometric evaluations, vasoactive factors, uterine artery pulsatility index, height and weight measurements. These measures will be repeated over 4 antenatal visits at 11-14, 18-22, 28-32 and above 34 weeks of gestation. Double data entry will be performed on Microsoft Access, and analysis of data will include the use of random effect models and receiver operating characteristic curves on Stata 11.2.

Discussion: The proposed study design will enable a longitudinal evaluation of the central aortic pressure changes as a marker for vascular compliance during pregnancy. As measures are repeated over time, the timing and severity of changes are detectable, and findings may yield important information on how aberrant vascular responses occur and its role in the early detection and prediction of hypertensive disorders.
\end{abstract}

Keywords: Central aortic pulse pressure, Pulsewave analysis, Pregnancy hypertensive disorders

\section{Background}

Hypertensive disorders occur in $10-15 \%$ of pregnancies, mainly with gestational hypertension at $10-12 \%$, followed by pre-eclampsia at $3-5 \%$ and severe pre-eclampsia at less than $1 \%[1,2]$. About $15 \%$ (ranged between 7 to $46 \%$ ) of women with gestational hypertension, may progress to preeclampsia and $9 \%$ to severe diseases [3]. Unlike gestational hypertension, preeclampsia is a multi-system disorder involving both maternal and fetal manifestations $[4,5]$.

\footnotetext{
* Correspondence: Kenneth.Kwek.Y.C@kkh.com.sg

'Department of Maternal and Fetal Medicine, KK Women's \& Children's Hospital, 100 Bukit Timah Road, Singapore 229899, Singapore

${ }^{2}$ Yong Loo Lin \& Saw Swee Hock School of Public Health, National University of Singapore, 10 Kent Ridge Crescent, Singapore 119260, Singapore Full list of author information is available at the end of the article
}

The origin of pre-eclampsia is rooted in the pathological development of placenta, of which is thought to be associated with angiogenic imbalance [6,7]. Downregulation of placental growth factor (PlGF) and upregulation of soluble fms like Tyrosine Kinase-1 (sFlt-1) have been observed as early as $8-10$ weeks of amenorrhoea [8] and derangement in these factors are associated with altered vascular endothelial responses in women with pre-eclampsia [9-13]. The relationship between endothelial function, PlGF and sFlt-1 appeared to be consistent [14], and subtle changes in the endothelium have been proposed to occur from first trimester onwards, prior to overt hypertension and proteinuria [6,15].

In the pathological development of gestational hypertension or pre-eclampsia, arterial stiffness or reduced arterial compliance occurs with diffuse vasoconstriction 
and increased peripheral vascular resistance arising from endothelial dysfunction $[6,16]$. This led to profound changes in the haemodynamic measures such as the central aortic and peripheral blood pressures. As suggested by Cnossen et al in 2008, brachial blood pressures discriminate poorly in a spectrum of hypertensive disorders. By contrast, central aortic pressures have been associated with better predictive values compared to conventional brachial blood pressures, and as early as less than 14 weeks gestation using pulse wave analysis [17,18]. Moreover, higher arterial stiffness is associated with preeclampsia compared with gestational hypertension or those with normal pregnancies [19].

It has been suggested that combined screening approaches involving ultrasonographic and biochemical markers from first to second trimester performed better than single markers alone in terms of sensitivity and/or specificity $[20,21]$. In studies with concurrent use of first trimester uterine artery pulsatility index (UAPI), biochemical (PlGF or pregnancy associated plasma protein A) and arterial blood pressure (mean arterial or central augmentation index), there were good detection rate and discriminatory power between variants of hypertensive disorders (gestational hypertension, early and late pre-eclampsia) [22-25]. The simultaneous use of these markers holds promise for early detection of preeclampsia as they are indicative of endothelial function and cardiovascular risk.

Although there are evidence to suggest that central aortic pressures are more robust than brachial blood pressures in prediction of cardiovascular outcomes in the general population [26-28], studies in pregnant women are lacking in numbers and sample size (Table 1). Current evidence points to the need for systematic measurements of central aortic pressures across pregnancy trimesters till the development of hypertension, and the adjustment for potential confounders. Study findings may unravel how the development of aortic stiffness in hypertensive disorders in pregnancy occurs, and their potential value if any, beyond brachial blood pressures in clinical application.

\section{Study aims}

This study aims to evaluate the role of central aortic stiffness in prediction of hypertensive disorders in pregnancy. The specific objectives are:

1. To identify gestation specific factors associated with central aortic stiffness as measured by central aortic pulse pressure (CAPP).

2. To measure the association between central aortic stiffness as quantified by CAPP and pregnancy associated hypertensive disorders

3. To determine the predictive performance of CAPP, sFlt-1 and PlGF, and UAPI measured at first trimester for early detection hypertensive disorder in pregnancy

\section{Methods}

\section{Study design and setting}

A prospective cohort of 1000 pregnant women will be recruited for follow-up till delivery and puerperium in KK Women's and Children's Hospital, a maternity hospital which handles an average of 12000 deliveries annually. This study has been approved by Institutional Review Board in 2010. Written informed consent will be obtained from all study participants.

\section{Study population and sampling method}

The study population will comprise mostly of Chinese, Malay and Indian ethnicities following the make-up of Singapore resident population [29]. Women with viable, singleton pregnancies at less than 14 weeks of amenorrhoea will be recruited, and those with multiple pregnancies, autoimmune or renal disease, diagnosed with aneuploidy or fetal anomaly will be excluded.

A convenient sampling of women seeking antenatal care at the outpatient clinics will be screened for study recruitment. Based on $80 \%$ eligibility and $50 \%$ participation rates, the target sample size of 1000 out of 2400 patients is attainable (Figure 1). The final sample size is expected at 850 having accounted for $15 \%$ dropout rate.

\section{Sample power calculation}

Assuming a $10 \%$ difference in incidence of hypertensive disorder between the lowest and highest quartiles of central aortic pulse pressure, and a base incidence of 5\%, a total of 207 participants are required in each quartile to achieve $80 \%$ power and at $5 \%$ alpha. The overall study sample therefore is at 828 participants with complete study follow-ups.

\section{Recruitment strategies}

Recruitment began in April 2011, at the antenatal specialist outpatient units and staffs at these units were briefed on the project. At screening, basic demographic factors such as education, employment and marital status are collected. Women who are unsure about study participation will be contacted within the week, and after 3 unsuccessful attempts of telephone contact within 2 weeks; patient will be deemed 'uncontactable'. Women who had consented into the study, and subsequently miscarried or decided to deliver elsewhere will be considered as 'ineligible'.

\section{Study procedures}

After written consent, the study participants will be followed-up till the diagnosis of hypertensive disorder in pregnancy (gestational hypertension or pre-eclampsia) 
Table 1 Studies evaluating central aortic pressures on pregnancy associated hypertensive disorders

\begin{tabular}{|c|c|c|c|c|c|c|c|}
\hline ID & $\begin{array}{l}\text { Author year/country } \\
\text { published }\end{array}$ & $\begin{array}{l}\text { Study design/ } \\
\text { sample size }\end{array}$ & $\begin{array}{l}\text { Study population } \\
\text { (Stage of pregnancy) }\end{array}$ & $\begin{array}{l}\text { Measures of } \\
\text { arterial stiffness }\end{array}$ & $\begin{array}{l}\text { Normal pregnancy } \\
\text { group }\end{array}$ & $\begin{array}{l}\text { Pre-eclampsia } \\
\text { group }\end{array}$ & $\begin{array}{l}\text { P Value } \\
\text { (Crude analysis) }\end{array}$ \\
\hline 1 & $\begin{array}{l}\text { Khalil [10] } 2008 \\
\text { United Kingdom }\end{array}$ & Cohort 218 & $\begin{array}{l}11-13+6 \text { weeks } \\
\text { of amenorrhea }\end{array}$ & $\mathrm{Al}$ & Al-OR1(Referent) & $\begin{array}{l}\text { Al-§ Odds Ratio } \\
21.3 \text { (95\% Cl5.5- } \\
82.3)\end{array}$ & $<0.001$ \\
\hline 2 & $\begin{array}{l}\text { Robb [15] } 2010 \\
\text { United Kingdom }\end{array}$ & Cohort 47 & $\begin{array}{l}\text { At } 16 \text { weeks of } \\
\text { amenorrhea/after } \\
\text { PE diagnosis }\end{array}$ & CAPP & $\begin{array}{l}\text { CAPP-Mean } 26 \\
\text { (SD1) } \mathrm{mmHg}\end{array}$ & $\begin{array}{l}\text { CAPP- Mean } \\
37 \text { (SD2) } \mathrm{mmHg}\end{array}$ & $<0.0001$ \\
\hline 3 & $\begin{array}{l}\text { Spasojevic [8] } \\
2005 \text { Australia }\end{array}$ & Cohort 99 & $\begin{array}{l}\text { 24-39 weeks of } \\
\text { amenorrhea }\end{array}$ & Al & $\begin{array}{l}\text { Al-Mean } 0.3 \\
\text { (SD7.4)\% }\end{array}$ & $\begin{array}{l}\text { Al-Mean } 24.2 \\
(\text { SD8.1)\% }\end{array}$ & $<0.0001$ \\
\hline 4 & $\begin{array}{l}\text { Khalil [9] } 2009 \\
\text { United Kingdom }\end{array}$ & $\begin{array}{l}\text { Nested case } \\
\text { control } 252\end{array}$ & $\begin{array}{l}11-13+6 \text { weeks } \\
\text { of amenorrhea }\end{array}$ & Al & $\begin{array}{l}\text { Al-= MOM } 0.8 \\
\text { (IQR0.5-1.2)\% }\end{array}$ & $\begin{array}{l}\text { Al-キ MOM 1.5 } \\
\text { (IQR1.3-1.8)\% }\end{array}$ & $\leq 0.002$ \\
\hline 5 & $\begin{array}{l}\text { Avni [14] } 2010 \\
\text { United States } \\
\text { of America }\end{array}$ & $\begin{array}{l}\text { Cross-sectional } \\
100\end{array}$ & $\begin{array}{l}\text { Any pregnancy } \\
\text { gestation }\end{array}$ & Al & $\begin{array}{l}\text { Al-Mean } 12.3 \\
\text { (SD7.4)\% }\end{array}$ & $\begin{array}{l}\text { Al-Mean } 32.4 \\
(\text { SD7.5)\% }\end{array}$ & 0.001 \\
\hline \multirow[t]{2}{*}{6} & $\begin{array}{l}\text { Kaihura [16] } 2009 \\
\text { United Kingdom }\end{array}$ & $\begin{array}{l}\text { Cross-sectional } \\
123\end{array}$ & $\begin{array}{l}\text { Any pregnancy } \\
\text { gestation }\end{array}$ & CAPP \& Al & $\begin{array}{l}\text { CAPP-Median } 27 \\
\text { (IQR24.2-31.5) } \\
\mathrm{mmHg}\end{array}$ & $\begin{array}{l}\text { CAPP-Median } 43.5 \\
\text { (IQR37.7-47.8) } \\
\mathrm{mmHg}\end{array}$ & $<0.0001$ \\
\hline & & & & & $\begin{array}{l}\text { Al-Mean } 4 \\
\text { (SD13.6)\% }\end{array}$ & $\begin{array}{l}\text { Al-Mean } 25.1 \\
\text { (SD11.2)\% }\end{array}$ & $<0.0001$ \\
\hline \multirow[t]{2}{*}{7} & $\begin{array}{l}\text { Ronnback [17] } \\
2005 \text { Finland }\end{array}$ & $\begin{array}{l}\text { Cross-sectional } \\
96\end{array}$ & $\begin{array}{l}\text { 30-42 weeks of } \\
\text { amenorrhea }\end{array}$ & CAPP \& Al & $\begin{array}{l}\text { CPP-Mean } 29 \\
\text { (Range 23-45) } \\
\mathrm{mmHg}\end{array}$ & $\begin{array}{l}\text { CPP- Mean } 39 \\
\text { (Range 28-65) } \\
\mathrm{mmHg}\end{array}$ & $<0.001$ \\
\hline & & & & & Al-Mean 4 (SD1)\% & Al-Mean 23 (SD2)\% & $<0.001$ \\
\hline \multirow[t]{2}{*}{8} & $\begin{array}{l}\text { Taspinar [18] } \\
2004 \text { Netherlands }\end{array}$ & $\begin{array}{l}\text { Cross-sectional } \\
122\end{array}$ & Third Trimester & CAPP \& Al & $\begin{array}{l}\text { CPP-Mean } 28 \text { (SD5) } \\
\text { mmHg }\end{array}$ & $\begin{array}{l}\text { CPP- Mean } 44 \\
\text { (SD17) } \mathrm{mmHg}\end{array}$ & $<0.05$ \\
\hline & & & & & $\begin{array}{l}\text { Al-Mean } 6.7 \\
\text { (SD14)\% }\end{array}$ & $\begin{array}{l}\text { Al-Mean } 31.1 \\
(\mathrm{SD} 12.4) \%\end{array}$ & $<0.05$ \\
\hline
\end{tabular}

CAPP $=$ Central Aortic Pulse Pressure in $\mathrm{mmHg}, \mathrm{Al}=$ Augmentation Index in\%,

* = Median (Interquartile range).

$\neq=$ Multiples of Median(Interquartile range).

$\S=$ Odds Ratio( $95 \%$ confidence interval).

or delivery. Central aortic blood pressures being the exposure of interest will be measured over 4 study visits at $11-14,18-22,28-32$ and above 34 weeks of gestation. Study follow-up for outcome ascertainment will continue till hospital discharge after delivery.

At study enrolment, baseline information on socioeconomic, personal medical and obstetric history will be obtained through an interviewer administered questionnaire. Other measures involving lifestyle behaviours, psychometric assessments and biophysical measures such as anthropometry, UAPI and blood sample for vasoactive factors (sFlt-1 and PIGF) will be done simultaneously at the 4 study visits as mentioned above (Figure 2).

\section{Central aortic pulse pressure measurement}

Central aortic pressures are derived from radial pulse wave analysis, obtained through a $\mathrm{BPro}{ }^{\circledR}$ device. It is a wrist watch like instrument which utilizes applanation tonometry on the radial pulse, developed by HealthStats, Singapore. The study participants are required to abstain from coffee intake for at least 0.5 hour, and prior to measurement, they are to be seated comfortably and rested for at least 5 minutes in a quiet room. From the right upper arm, brachial blood pressures are repeated three times at intervals of $30-60$ seconds using an oscillometric device by HealthStats (MC3100), whereby difference between each measurement should not differ by more than $10 \mathrm{mmHg}$ for either systolic or diastolic pressures. After achieving a stable reading, the systolic and diastolic averages will be used to calibrate the radial pulse wave forms and continuous sampling of the latter will ensue for 40-60 seconds.

Central aortic pulse pressure as a measure of arterial stiffness is the difference in pressure between central aortic systolic and brachial diastolic pressures in $\mathrm{mmHg}$. This measure is dependent on the use of radial pulse wave analysis to derive central aortic systolic pressure which has shown good agreement with invasive measurements using cardiac catheterization [30], and that diastolic pressure is stable between central and peripheral (brachial) sites $[31,32]$. An internal validation has been conducted for the measurement of central aortic pulse pressure, and the coefficient of variation is at $1.9 \%$.

\section{Other measures}

Questionnaires are employed to gather information pertaining to socio-economic, lifestyle, sleep and maternal 


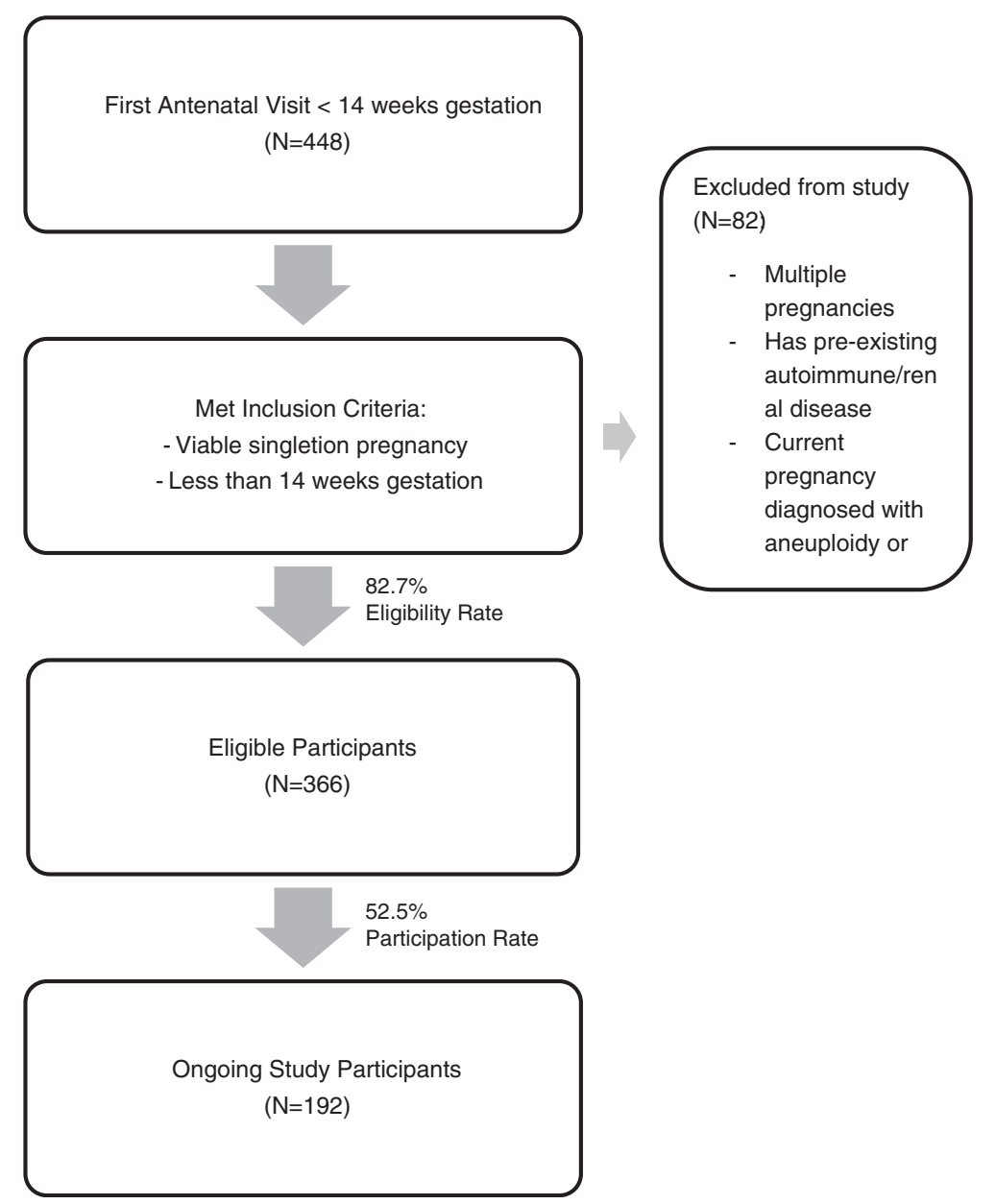

Figure 1 Target sample at antenatal outpatient clinics (study status as of November 2011).

coping during pregnancy. Interviewer administered structured questionnaires were used to collect demographic data on variables such as maternal and partner's date of birth, race, education, occupation, type of housing, household size and income; life style variables such as alcohol and coffee intake, physical exercise and daily activities and smoking habits; and lastly personal or family history of gestational diabetes, hypertension or pre-eclampsia.

Validated self-administered questionnaires are used to determine sleep and maternal coping in pregnancy. Assessment of sleeping habit are done through Pittsburgh Sleep Quality Index [33]; and maternal coping during pregnancy through psychometric assessments on maternal stress, anxiety and depression scores using Stress Trait \& Anxiety Inventory [34], Perceived Stress Scale [35], Roesch Questionnaire [36] and Edinburgh Postnatal Depression Scale [37] respectively.

All self-administered questionnaires are available in Chinese and Malay versions. These questionnaires are translated forward and backward into English for all except Stress Trait \& Anxiety Inventory, as it is available in both languages. Both interviewer and self-administered questionnaires are administered by trained staffs that are conversant in both English and Chinese or Malay.

Biophysical measurements including anthropometry, ultrasound doppler (UAPI) and serum biomarkers for sFlt-1 and PlGF are done by hospital nurses, sonographers and laboratory technologists that are accredited to perform these procedures. Serum samples would be aliquoted and stored in $-80^{\circ} \mathrm{C}$ at the research laboratory.

\section{Assessment of hypertensive disorder in pregnancy}

The definitions of hypertensive disorder in pregnancy are based on the criteria as specified by Working Group on High Blood Pressure in Pregnancy [4,38]. Therefore, gestational hypertension is defined as new onset of hypertension in pregnancy with brachial systolic pressure at $140 \mathrm{mmHg}$ and above, or a diastolic pressure of $90 \mathrm{mmHg}$ or above on repeated measurements of more than 6 hours interval within 1 week after 20 weeks gestation without proteinuria. In pre-eclampsia however, the definition includes both hypertension and proteinuria at above $0.3 \mathrm{~g}$ 


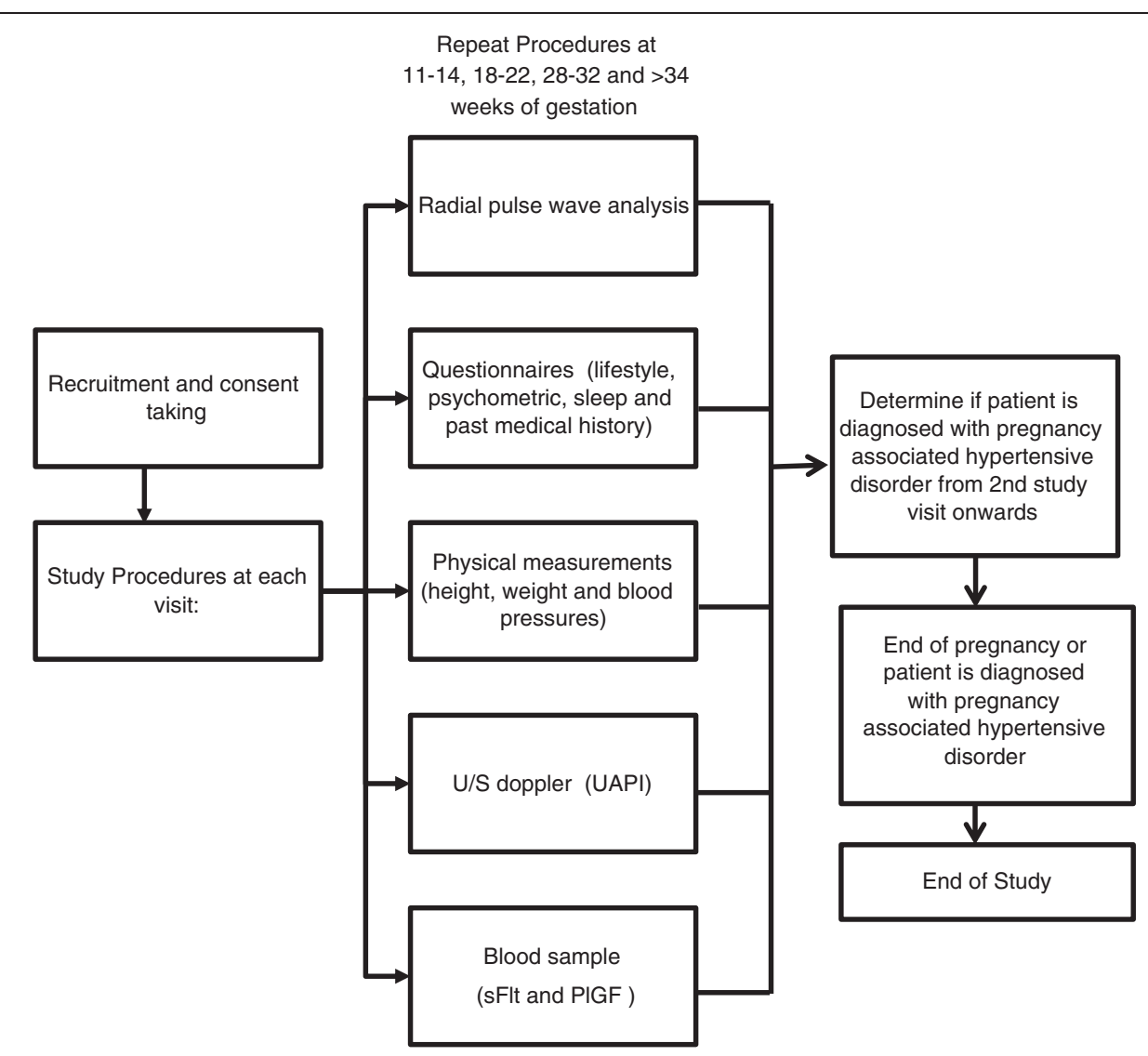

Figure 2 Flowchart for study procedures.

protein/24 h (or in emergency cases only a dipstick $>1+$ on more than one occasion or $\geq 30 \mathrm{mg} / \mathrm{dL}$ protein in a spot urine if a 24 hour urine protein collection cannot be obtained). Outcome ascertainment will be done by trained medical personnel based on the above criteria.

\section{Data management}

Data entry will be done by 2 independent research staff in 2 separate access databases. Weekly entry of raw data will be done to ensure timely clearance. At data verification, databases will be locked and no entries are made until all queries are resolved. Training and simulations for data entry have been conducted for familiarization purposes. Moreover, protocols for data entry, verification and cleaning are provided to staff involved in data entry and cleaning.

\section{Statistical methods}

At the end of data validation and cleaning, data will be prepared for analysis through reduction of some variables into fewer categories such as occupation and generation of new variables such as body mass index. Data analysis will be carried out using Stata version 11.2 (Statacorp, College Station, Texas). Analysis will include distribution of sample characteristics in relation to gestational hypertension and pre-eclampsia in proportions and central tendencies; and their crude associations using mixed models for correlated data.

Selection of potential risk factors will be based on biological plausibility and at a significance level of 0.2 for subsequent modelling. Receiver Operator Characteristic curves will be employed to assess the predictive capabilities of tests. Sensitivity and likelihood ratios will be reported based on $5 \%$ and $10 \%$ false positive rates. Missing data will be assessed for bias and depending on its nature, sensitivity analysis or multiple imputation techniques may be employed to deal with the loss of information in the dataset.

\section{Discussion}

Recruitment of study participants begun in April 2011 and by November 2011, 366 eligible pregnant women were screened and 192 (52.5\%) had consented into the study. The recruitment rate was slower than expected as recruitment was temporally suspended from late August 2011 to end October due to staffing issues. During this period, study follow-ups were on-going to minimize disruption to study flow. Recruitment resumed in early 
November, with 2 research coordinators actively screening for eligible participants at antenatal outpatient clinics.

Amongst the 192 study participants, 84 (44\%) were Chinese, 60 (31\%) Malays, 19 (10\%) Indians and 29 (15.1\%) were of other ethnicities. The mean age was at 30 years old, ranging from 19 to 44 years old. About 47 (25\%) received tertiary education, and 138 (73\%) were employed at the time of recruitment. Preliminary comparison between those who consented and refused study participation showed that age, education level and employment status were similar. However, there were significant racial differences amongst those who refused participation, whereby Indians tended to refuse participation (64.2\%) and Malays tended to participate $(60.6 \%)$, p value $=0.036$.

From literature review, elevations in central aortic pressures (augmentation index, systolic and diastolic pressures) are greatest amongst women with pre-eclampsia, followed by gestational hypertension compared to women with normal pregnancies [16,39-43]. Predictive performance using central aortic augmentation index measured at 11-14 weeks of amenorrhoea has $50-57 \%$ sensitivity in detecting pre-eclampsia $[17,18]$ as compared to $24-35 \%$ for brachial systolic, diastolic and mean arterial blood pressures [15].

Although current reports on these measures provide valuable information about circulatory changes associated with hypertension disorders in pregnancy, presently they do not infer central aortic pressures ability to discriminate pre-eclampsia from gestational hypertension or normal pregnancies. The observed difference in central aortic pressures may be flawed due to the crosssectional approach that utilized concurrent measurement of central aortic pressures and pre-eclampsia [44]. It is therefore difficult to establish temporality i.e. elevation of central aortic pressures prior to pre-eclampsia.

Furthermore, there are limitations associated with interpretation of these indices. Firstly, the validity of the central aortic augmentation index is questionable as they were derived from a generalized transfer function which assumed similar baseline characteristics for its subjects [45-47]. To date, only central aortic systolic pressure has been shown to have excellent correlation and agreement with direct measurement of aortic root pressure during cardiac catheterization[30]. Secondly, inadequate adjustment for factors that affect central aortic pressures may possibly invalidate the reported difference as observed between pre-eclampsia, gestational hypertension and normal pregnancies [39-41,43]. Lastly, as most measures were taken at one singular event at $2^{\text {nd }}$ trimester onwards, the onset and magnitude of insult i.e. endothelial dysfunction leading to arterial stiffness is uncertain.

Therefore, the rationale of the study aim is to systematically measure changes in central aortic stiffness and associated factors beginning from first trimester onwards to account for gestation specific physiological changes as well as for alterations in environmental exposures and shifts in the mental and emotional states of pregnant women, prior to the development of gestational hypertension or pre-eclampsia. Secondly, central aortic pulse pressure is used as a measure of central aortic stiffness instead of central augmentation index, as it is a direct derivation from the difference between central aortic systolic and diastolic pressures, without the assumptions of a generalized transfer function as applied to the central aortic augmentation index.

The cohort design will resolve issues associated with temporality as reported in most studies using cross sectional evaluation. However, losses to follow-up may potentially introduce attrition bias into the study. Therefore retention of study participants will be important and this may be achieved through rapport building and close communication with the study participants. Selection bias may occur due to the convenient sampling technique and an analysis on the socio-economic variables of women who refused study participation to evaluate the occurrence of selection bias will be done.

In conclusion, as raised arterial pressure is a manifestation endothelial dysfunction, targeted measurement of central aortic pressures in this study may yield important information how these aberrant responses occur and its role early detection and prediction of hypertensive disorders in pregnancy.

\section{Competing interests}

The authors have no competing interests.

\section{Authors' contributions}

$\mathrm{KK}, \mathrm{KH}, \mathrm{GY}$ and $\mathrm{WY}$ led the conceptualization and design of the original project, prepared the proposal and obtained funding. WY, SM and KK developed this current protocol and manuscript with input from $\mathrm{KH}$ and GY. All authors reviewed and approved the final version of manuscript.

\section{Authors' information}

WY: BNurs, Dip LSHTM, MSc Epidemiology. This protocol was written as part of the $\mathrm{PhD}$ requirement.

SM: MBBS, MPH, PhD, FAMS. Professor of Epidemiology and Ophthalmology. Vice Dean (Research), Yong Loo Lin School of Medicine

KK: MBBS, M Med (O\&G), MRANZCOG, MRCOG Associate Professor, Senior

Consultant, Head of Maternal and Fetal Department and Chief Executive Officer of KK Women's \& Children's Hospital

KH: MBBS, MRCOG, M Med (O\&G), FAMS, FRCOG Associate Professor, Senior

Consultant, Division Chairman (O\&G), Head of Perinatal Audit and

Epidemiology

GY: MBBS, FRCOG, FAMS Professor, Chief of Obstetrics, Head \& Senior

Consultant of Obstetric Ultrasound and Prenatal Diagnosis Unit

\section{Acknowledgements}

This study is nested in a cohort study entitled "Improving the adverse out comes of pregnancy- clinical and translational research programme in perinatal medicine", funded under a Project Programme Grant by National Medical Research Council of Singapore.

\section{Author details}

'Department of Maternal and Fetal Medicine, KK Women's \& Children's Hospital, 100 Bukit Timah Road, Singapore 229899, Singapore. ${ }^{2}$ Yong Loo Lin \& Saw Swee Hock School of Public Health, National University of Singapore, 
10 Kent Ridge Crescent, Singapore 119260, Singapore. ${ }^{3}$ Saw Swee Hock School of Public Health, National University of Singapore, 10 Kent Ridge Crescent, Singapore 119260, Singapore.

Received: 4 February 2012 Accepted: 29 November 2012

Published: 26 December 2012

\section{References}

1. Loi K, Khoo CK, Tan KH, Yeo GSH, Kwek K: A review of 93 cases of severe pre-eclampsia in Singapore: are there risk factors for complications. Singapore Med J 2007, 48(9):808-812.

2. Nelson-Piercy C: Handbook of Obstetric Medicine. London: Martin Dunitz Ltd; 2002.

3. Barton JR, O'Brien JM, Bergauer NK, Jacques DL, Sibai BM: Mild gestational hypertension remote from term: progression and outcome. Am J Obstet Gynecol 2001, 184(5):979-983.

4. National High Blood Pressure Education Program Working Group on High Blood Pressure in P: Report of the National High Blood Pressure Education Program Working Group on high blood pressure in pregnancy. Am J Obstet Gynecol 2000, 183(1):S1-S22.

5. Walker JJ: Pre-eclampsia. Lancet 2000, 356(9237):1260-1265.

6. Wang A, Rana S, Karumanchi SA: Preeclampsia: the role of angiogenic factors in its pathogenesis. Physiology 2009, 24:147-158

7. Venkatesha S, Toporsian M, Lam C, Hanai J, Mammoto T, Kim YM, Bdolah Y, Lim KH, Yuan HT, Libermann TA, et al: Soluble endoglin contributes to the pathogenesis of preeclampsia. Nat Med 2006, 12:642-649.

8. Romero RNJ, Espinoza J, Todem D, Fu W, Chung H, Kusanovic JP, Gotsch F, Erez O, Mazaki-Tovi S, Gomez R, Edwin S, Chaiworapongsa T, Levine RJ, Karumanchi SA: A longitudinal study of angiogenic (placental growth factor) and anti-angiogenic (soluble endoglin and soluble vascular endothelial growth factor receptor-1) factors in normal pregnancy and patients destined to develop preeclampsia and deliver a small for gestational age neonate. J Matern Fetal Neonatal Med 2008, 21(1):9-23.

9. Erez ORR, Espinoza J, Fu W, Todem D, Kusanovic JP, Gotsch F, Edwin S, Nien JK, Chaiworapongsa T, Mittal P, Mazaki-Tovi S, Than NG, Gomez R, Hassan SS: The change in concentrations of angiogenic and anti-angiogenic factors in maternal plasma between the first and second trimesters in risk assessment for the subsequent development of preeclampsia and small-for-gestational age. J Matern Fetal Neonatal Med 2008, 21(5):279-287.

10. Verlohren S, Galindo A, Schlembach D, Zeisler H, Herraiz I, Moertl M, Pape J, Dudenhausen JW, Denk B, Stephan H: An automated method fo rhte determination of the sFIt-1/PIGF ratio in the assessment of preeclampsia. Am J Obstet \& Gynaecol 2010, 201:e1-e11.

11. Levine RJ, Maynard SE, Qian C, Lim K-H, England LJ, Yu KF, Schisterman EF, Thadhani R, Sachs BP, Epstein FH, et al: Circulating angiogenic factors and the risk of preeclampsia. N Engl J Med 2004, 350(7):672-683.

12. Vatten LJ, Eskild A, Nilsen TIL, Jeansson S, Jenum PA, Staff AC: Changes in circulating level of angiogenic factors from the first to second trimester as predictors of preeclampsia. Am J Obstet Gynecol 2007, 196(3):239.e231-239.e236.

13. Rana S, Karumanchi SA, Levine RJ, Venkatesha S, Rauh-Hain JA, Tamez H, Thadhani R: Sequential changes in antiangiogenic factors in early pregnancy and risk of developing preeclampsia. Hypertension 2007, 50 (1):137-142

14. Lapaire O, Shennan A, Stephan $\mathrm{H}$ : The preeclampsia biomarkers soluble fms-like tyrosine kinase- 1 and placental growth factor: current knowledge, clinical implications and future application. European Journal of Obstetrics \& Gynecology 2010, 151:122-129.

15. Cnossen JS, Vollebregt KC, Vrieze N, Riet GT, Mol BWJM, Franx A, Khan KS, van der Post JAM: Accuracy of mean arterial pressure and blood pressure measurements in predicting pre-eclampsia: systematic review and metaanalysis. BMJ 2008, 336(7653):1117-1120.

16. Spasojevic M, Smith SA, Morris JM, Gallery ED: Peripheral arterial pulse wave analysis in women with pre-eclampsia and gestational hypertension. BJOG 2005, 112(11):1475-1478.

17. Khali A, Cowans NJ, Spencer K. Goichman S, Meiri H, Harrington K. Firsttrimester markers for the prediction of pre-eclampsia in women with apriori high risk. Ultrasound Obstet Gynecol 2010, 35(6):671-679.

18. Khalil AA, Cooper DJ, Harrington KF: Pulse wave analysis: a preliminary study of a novel technique for the prediction of pre-eclampsia. BJOG 2009, 116(2):268-276. discussion 276-267.
19. Hausvater A, Giannone T, Sandoval Y-HG, Doonan RJ, Antonopoulos CN, Matsoukis IL, Petridou ET, Daskalopoulou SA: The association between preeclampsia and arterial stiffness. J Hypertens 2012, 30:17-33.

20. Giquere Y, Charland M, Bujold E, Bernard N, Grenier S, Rousseau F, Lafond J, Legare F, Forest J-C: Combining biochemical and ultrasonographic markers in predicting preeclampsia: a systematic review. Clin Chem 2010, 56(3):361-375

21. Gagnon A, Wilson RD, Audibert F, Allen VM, Blight C, Brock JA, Desilets VA, Johnson JA, Langlois S, Summers A, et al: Obsterical complications assocaited with abnormal maternal serum analytes. J Obstet Gynaecol Can 2008, 30(10):918-949.

22. Poon LCY, Kametas NA, Maiz N, Akolekar R, Nicolaides KH: First-trimester prediction of hypertensive disorders in pregnancy. Hypertension 2009, 53:812-818

23. Akolekar R, Zaragoza E, Poon LCY, Pepes S, Nicolaides KH: Maternal serum placental growth factor at $11+0$ to $13+6$ weeks of gestation in the prediction of pre-eclampsia. Ultrasound Obstet Gynecol 2008, 32(6):732-739.

24. Stepan H, Unversucht A, Wessel N, Faber R: Predictive value of maternal angiogenic factors in second trimester pregnancies with abnormal uterine perfusion. Hypertension 2007, 49(4):818-824.

25. Kasdaglis T, Aberdeen G, Turan O, Kopelman J, Atlas R, Jenkins C, Blitzer M, Harman C, Baschat AA: Placental growth factor in the first trimester: relationship with maternal factors and placental Doppler studies. Ultrasound Obstet Gynecol 2009, 35(3):280-285.

26. Mancia G, De Backer G, Dominiczak A, Cifkova R, Fagard R, Germano G, Grassi G, Heagerty A, Kjeldsen S, Laurent S, et al: 2007 ESH-ESC Practice guidelines for the management of arterial hypertension: ESH-ESC Task Force on the management of arterial hypertension. J Hypertens 2007, 25(9):1751-1762.

27. Williams B, Lacy PS: Central aortic pressure and clinical outcomes. J Hypertens 2009, 27:1123-1125

28. Agabiti-Rosei E, Mancia G, O'Rourke MF, Roman MJ, Safar ME, Smulyan H, Wang J-G, Wilkinson IB, Williams B, Vlachopoulous C: Central blood pressure measurements and antihypertensive therapy, a consensus document. Hypertension 2007, 50:154-160

29. Singapore Department of Statistics: Census of Population 2010 - Advance Census Release. Singapore: Singapore Department of Statistics; 2010.

30. Williams B, Lacy PS, Yan P, Hwee C-N, Liang C, Ting C-M: Development and validation of a novel method to derive central aortic systolic pressure from the radial pressure waveform using an $n$-point moving average method. J Am Coll Cardiol 2011, 57(8):951-961.

31. Williams $B$, Lindholm LH, Sever P: Systolic pressure is all that matters. Lancet 2008, 371:2219-2221.

32. Khalil AJE, Cooper D, Harrington K: Wave analysis in normal pregnancy: a prospesctive longitudinal study. PLoS One 2009, 4(7):e6314.

33. Buysse DJ, Reynolds CF, Monk TH, Berman SR, Kupfer DJ: The Pittsburgh Sleep Quality Index (PSQI): a new instrument for psychiatric research and practice. Psychiatry Res 1989, 28(2):193-213.

34. Spielbergeer CD: State-Trait Anxiety Inventory: A comprehensive bibliography. 2nd edition. Palo Alto, CA: Consulting Psychologists Press; 1983.

35. Cohen S, Karmarck T, Mermelstein R: A global measure of perceived stress. Journal of Health and Social Behaviour 1983, 24:385-396.

36. Roesch SC, Dunkel-Schetter C, Woo G, Hobel CJ: Modeling the types and timing of stress in pregnancy. Anxiety Stress Coping 2004, 17(1):87-102.

37. Cox JL, Holden JM, Sagovsky R: Detection of postnatal depression: development of the 10-item edinburgh postnatal depression scale. Br J Psychiatry 1987, 150:782-786.

38. AmericanCollegeofObstetricianandGynaecologist: Diagnosis and management of pre-eclampsia and eclampsia. ACOG Practice Bulletin No. 33. Obstet Gynecol 2002, 99:159-167.

39. Kaihura C, Savvidou MD, Anderson JM, McEniery CM, Nicolaides KH: Maternal arterial stiffness in pregnancies affected by preeclampsia. Am J Physiol Heart Circ Physiol 2009, 297(2):H759-764.

40. Ronnback M, Lampinen K, Groop PH, Kaaja R: Pulse wave reflection in currently and previously preeclamptic women. Hypertens Pregnancy 2005 24(2):171-180

41. Avni B, Frenkel G, Shahar L, Golik A, Sherman D, Dishy V: Aortic stiffness in normal and hypertensive pregnancy. Blood Press 2010, 19(1):11-15.

42. Robb AO, Mills NL, Din JN, Smith IB, Paterson F, Newby DE, Denison FC: Influence of the menstrual cycle, pregnancy, and preeclampsia on arterial stiffness. Hypertension 2009, 53(6):952-958. 
43. Elvan-Taspinar A, Franx A, Bots ML, Bruinse HW, Koomans HA: Central hemodynamics of hypertensive disorders in pregnancy. Am J Hypertens 2004, 17(10):941-946.

44. Gordis L: Epidemiology. 4th edition. Philadelphia: Saunders Elsevier; 2009

45. Hope SA, Meredith IT, Cameron JD: Arterial transfer functions and the reconstruction of central aortic waveforms: myths, controversies and misconceptions. J Hypertens 2008, 26:4-7.

46. Khoshdel AR: Time to end a doubt: Is pulse wave analysis a valid measure for central arterial blood pressure and arterial stiffness? J Hypertens 2007, 25(3):724-725.

47. Williams B, Lacy PS: Central haemodynamics and clinical outcomes: going beyond brachial blood pressure? Eur Heart J 2010, 31:1819-1822.

doi:10.1186/1471-2393-12-160

Cite this article as: Lim et al: A cohort evaluation on arterial stiffness and hypertensive disorders in pregnancy. BMC Pregnancy and Childbirth 2012 12:160

\section{Submit your next manuscript to BioMed Central and take full advantage of:}

- Convenient online submission

- Thorough peer review

- No space constraints or color figure charges

- Immediate publication on acceptance

- Inclusion in PubMed, CAS, Scopus and Google Scholar

- Research which is freely available for redistribution 